\title{
Butenolide derivatives from the fungus Aspergillus terreus and their radical scavenging activity and protective activity against glutamate-induced excitotoxicity
}

\author{
Hahk-Soo Kang ${ }^{1}$ and Jong-Pyung Kim² ${ }^{2 *}$
}

\begin{abstract}
The organic extract of cultured Aspergillus terreus displayed scavenging activity against ABTS ${ }^{++}$and DPPH free radicals, and protective activity against glutamate-induced excitotoxicity in N18-RE-105 neuroblastoma-retina hybrid cells. Bioassay-guided fractionation of the active organic extract led to the isolation of total six butenolide derivatives, including one new metabolite, named butyroscavin (1), and five previously described metabolites, butyrolactones I (2), II (3), III (4), and VII (5), and aspernolide E (6). The planar structure of butyroscavin (1) was determined by the analysis of spectroscopic data including ESIMS (electrospray ionization mass spectrometry), and 1D and 2D NMR (nuclear magnetic resonance). The absolute configuration of butyroscavin (1) was assigned by comparison of the specific rotation with those of known compounds that share the same chiral carbon. All isolated compounds were active in the radical scavenging assay, whereas only butyrolactones I (2) and VII (5) exhibited protective activity against the glutamate-induced excitotoxicity with the $\mathrm{EC}_{50}$ of 130.1 and $91.9 \mu \mathrm{M}$, respectively.
\end{abstract}

Keywords: Butenolides, Natural products, Antioxidants, Neuroprotection, Aspergillus

\section{Introduction}

High glutamate concentration in the synaptic cleft can cause excitotoxicity in neurons that has been known to be one of the major mechanisms of neurodegeneration in progressive neurological disorders such as Parkinson's disease and Alzheimer's disease [4]. Underlying molecular mechanism of excitotoxicity involves excessive generation of reactive oxygen species in hyperexcited neurons [1]. This suggests that the administration of antioxidants could be effective in slowing the progression of neurological disorders by protecting neurons from oxidative damages $[9,12]$. As a part of our ongoing effort to search for neuroprotective metabolites from natural sources, we screened our library of fungal extracts for antioxidant activity as well as protective activity against the glutamate

\footnotetext{
${ }^{*}$ Correspondence: kimjp@kribb.re.kr

${ }^{2}$ Korea Research Institute of Bioscience and Biotechnology (KRIBB),

Cheongju, Chungbuk 28116, Republic of Korea

Full list of author information is available at the end of the article
}

induced excitotoxicity, and the extract of the cultured Aspergillus terreus exhibited significant activities in our screening. Thus, bioassay-guided fractionation was performed to identify active metabolites from the active extract. Here, we report the isolation of six butenolide derivatives from the culture of a soil fungus $A$. terreus that include one new metabolite, named butyroscavin (1), and five previously reported metabolites, butyrolactones I (2) [8], II (3) [10], III (4) [10] and VII (5) [5] and aspernolide $\mathrm{E}(6)$ [6].

\section{Materials and methods}

\section{General experimental procedures}

UV (Ultraviolet) spectra was acquired on a Pharmacia Biotech Ultrospec 3000 UV/Visible spectrometer. Shimadzu $8400 \mathrm{~s}$ FT-IR spectrometer was used to obtain FT-IR (Fourier transform infrared) spectra. 1D and 2D NMR (nuclear magnetic resonance) spectra of all isolated compounds were obtained using a Varian INOVA$400 \mathrm{NMR}$ spectrometer. $\mathrm{MeOH}-d_{4}$ was used as a solvent 
for all NMR experiments, and signals were referenced against solvent signals. Finnigan Navigator 30086 and a JMS-700 MSTATION high-resolution mass spectrometer systems were used to acquire low resolution ESIMS (electrospray ionization) and high resolution EIMS (electron ionization) spectra, respectively. All preparative HPLC (high-performance liquid chromatography) experiments were performed using a Waters HPLC system equipped with a Waters 996 photodiode array detector using a reversed-phase column (J'sphere ODS-H80, $150 \times 20 \mathrm{~mm}, 4 \mu \mathrm{m}, \mathrm{YMC}$ Co.).

\section{Extraction and isolation}

The fungus $A$. terreus was acquired from the KRIBB microbial culture collection (Deposit No. KCTC 08095BP). For seed culture, the spores were inoculated into $150 \mathrm{ml}$ YM liquid media ( $0.3 \%$ yeast extract, $0.3 \%$ malt extract, $0.5 \%$ tryptone, and $1 \%$ glucose) and cultured for three days at $28^{\circ} \mathrm{C}$ with shaking $(147 \mathrm{rpm})$. Three milliliter of the seed culture was used for the inoculation into each fresh $150 \mathrm{~mL}$ YM media. Total $1.5 \mathrm{~L}(10 \times 150 \mathrm{~mL})$ culture was incubated in the same condition as those used for the seed culture. For compound isolation, the cultures were harvested and separated between mycelium and broth by filtration using the Whatman filter paper. The mycelium was extracted with $80 \%$ aqueous acetone overnight and dried in vacuo. The mycelium extract was combined back with the broth, and then the mixture was extracted stepwise with hexane, $\mathrm{CHCl}_{3}$ (chloroform), EtOAc (ethylaceate) and $\mathrm{BuOH}$ (buthanol). Compound isolation was guided by radical scavenging activity against both ABTS $^{*+}$ and DPPH radicals. The EtOAc layer showed the highest activity in both assays, and was thus fractionated by silica column chromatography with a solvent gradient $\left(\mathrm{CHCl}_{3}: \mathrm{MeOH}\right)$ from 50:1 to $1: 1$. Active fractions were combined, and then further subjected to a Sephadex LH-20 size exclusion column chromatography eluting with $\mathrm{MeOH}$. Lastly, reversedphase HPLC (flow rate $7.0 \mathrm{ml} / \mathrm{min}$ ) of the active fractions using the $\mathrm{C}_{18}$ column (cosmosil, $5 \mathrm{C}_{18}$-MS-II column, $150 \times 20 \mathrm{~mm}$ ) and $45 \%$ aqueous ACN (acetonitrile) led to the isolation of pure compounds $\mathbf{1}(25.2 \mathrm{mg}), \mathbf{2}(76.5 \mathrm{mg})$, 3 (103.2 mg), 4 (5.6 mg), 5 (20.9 mg), and 6 (19.5 mg).

\section{Structural elucidation of compound 1}

Butyroscavin (1). Yellow, amorphous powder; $[\alpha]^{20}{ }_{D}+$ 49.41 (c $0.5, \mathrm{MeOH}$ ); UV (MeOH) $\lambda \max (\log \varepsilon) 203.7$ (4.54) and 305.8 (4.18) nm; IR (KBr) 3366, 1739, 1610, 1515, and $1442 \mathrm{~cm}^{-1} ;{ }^{1} \mathrm{H}$ and ${ }^{13} \mathrm{C}$ NMR data, see Table 1; ESIMS (negative ion mode) $\mathrm{m} / \mathrm{z} 369.5[\mathrm{M}-\mathrm{H}]^{-}$; HREIMS $\mathrm{m} / \mathrm{z} 370.1065[\mathrm{M}]^{+}$(calcd. for $\left.\mathrm{C}_{20} \mathrm{H}_{18} \mathrm{O}_{7}, 370.1053\right)$.
Table 1 NMR data for butyroscavin (1)

\begin{tabular}{|c|c|c|c|}
\hline \multirow[t]{2}{*}{ Position } & \multicolumn{2}{|c|}{ Butyroscavin (1) } & \multirow[b]{2}{*}{ HMBC } \\
\hline & ${ }^{13} \mathrm{C}^{a}$ & ${ }^{1} \mathrm{H}$ (mult.) $)^{a}$ & \\
\hline 1 & 169.6 & & \\
\hline 2 & 138.6 & & \\
\hline 3 & 128.0 & & \\
\hline 4 & 85.7 & & \\
\hline 5 & 38.3 & $3.42(2 \mathrm{H}, \mathrm{s})$ & $C-4, C-1^{\prime \prime}, C-2^{\prime \prime}$ \\
\hline 6 & 169.8 & & \\
\hline 7 & 62.5 & $4.25(2 \mathrm{H}, \mathrm{q}, J=7.2 \mathrm{~Hz})$ & $C-8, C-6$ \\
\hline 8 & 13.0 & $1.21(3 \mathrm{H}, \mathrm{t}, \mathrm{J}=7.2 \mathrm{~Hz})$ & $C-7$ \\
\hline $1^{\prime}$ & 121.9 & & \\
\hline $2^{\prime}$ & 129.2 & $7.60(2 \mathrm{H}, \mathrm{d}, J=8.8 \mathrm{~Hz})$ & $C-3, C-2^{\prime}, C-4^{\prime}$ \\
\hline $3^{\prime}$ & 115.4 & $6.87(2 \mathrm{H}, \mathrm{d}, \mathrm{J}=8.8 \mathrm{~Hz})$ & $C-1^{\prime}, C-3^{\prime}, C-4^{\prime}$ \\
\hline $4^{\prime}$ & 158.2 & & \\
\hline $1^{\prime \prime}$ & 124.1 & & \\
\hline $2^{\prime \prime}$ & 131.3 & $6.64(2 \mathrm{H}, \mathrm{d}, \mathrm{J}=8.8 \mathrm{~Hz})$ & $C-5, C-2^{\prime \prime}, C-4^{\prime \prime}$ \\
\hline $3^{\prime \prime}$ & 114.4 & $6.51(2 \mathrm{H}, \mathrm{d}, \mathrm{J}=8.8 \mathrm{~Hz})$ & $C-1^{\prime \prime}, C-3^{\prime \prime}, C C-4^{\prime \prime}$ \\
\hline $4^{\prime \prime}$ & 156.3 & & \\
\hline
\end{tabular}

\section{Radical scavenging activity assay}

Radical scavenging activity of the crude extracts as well as pure compounds was evaluated using stable $\mathrm{ABTS}^{\cdot+}$ [15] and DPPH [7] free radicals. $\alpha$-Tocopherol, BHA (Butylated hydroxanisole), and Trolox were used as reference compounds. Reference and test compounds were dissolved in DMSO at various concentrations. $\mathrm{ABTS}^{*+}$ radical scavenging activity was measured using the method previously published [15]. $\mathrm{ABTS}^{*}{ }^{+}$free radicals were produced by combining $7.0 \mathrm{mM}$ ABTS and $2.45 \mathrm{mM}$ potassium persulfate solutions. The $\mathrm{ABTS}^{\cdot+}$ free radical solution was diluted with water to an absorbance of $0.7 \pm 0.025$ at $734 \mathrm{~nm}$, and then $190 \mu \mathrm{L}$ of the solution was mixed with $10 \mu \mathrm{L}$ of each test compound in DMSO. After $7 \mathrm{~min}$, the absorbance was recorded at $734 \mathrm{~nm}$. For the DPPH assay, $150 \mu \mathrm{L}$ of a $0.15 \mathrm{mM}$ DPPH solution in $\mathrm{EtOH}$ was mixed with $10 \mu \mathrm{L}$ of each test compound in DMSO. The reaction mixtures were left at room temperature for $10 \mathrm{~min}$, and then absorbance was measured at $517 \mathrm{~nm}$ on an ELISA plate reader.

The radical activity was expressed as a percentage activity using the following equation:

Scavenging activity $(\%)=\left(1-\mathrm{A}_{\text {test }} / \mathrm{A}_{\text {control }}\right) \times 100$ where $A_{\text {test }}$ is the absorbance of a sample at a given concentration, and $\mathrm{A}_{\text {control }}$ is the absorbance recorded for a blank (DMSO). $\mathrm{EC}_{50}$ is defined as the concentration of a sample that causes $50 \%$ loss of the $\mathrm{ABTS}^{*+}$ and DPPH radicals. 


\section{Glutamate induced excitotoxicity assay}

Protective activity against glutamate-induced excitotoxicity was evaluated using N18-RE-105 neuroblastomaretina hybrid cells [2]. The cells were propagated at $37^{\circ} \mathrm{C}$ in high glucose DMEM (Dulbecco's modified Eagle's) medium containing 9.7\% FBS (fetal bovine serum), 4.8\% Horse Serum, 1.9\% HAT (hypoxanthine-aminopterinthymidine) and $0.1 \%$ Sodium bicarbonate at $37{ }^{\circ} \mathrm{C}$ in $5 \%$ $\mathrm{CO}_{2}$. Cells growing in log phase were collected by trypsinization. Then, a total of 50,000 cells were seeded onto each well of a 96-well plate and incubated overnight at $37{ }^{\circ} \mathrm{C}$ in $5 \% \mathrm{CO}_{2}$. Samples dissolved in DMSO were sequentially diluted with phosphate buffered saline, and added to appropriate wells together with the $400 \mathrm{mM}$ glutamate solution $(7 \mu \mathrm{L}$ of each). The cells were incubated for $24 \mathrm{~h}$, and the cell viability was measured using EZ-cytox Cell Viability Kit (DoGen). Briefly, each well was added with $10 \mu \mathrm{L}$ of the Ez-cytox solution and incubated for $3 \mathrm{~h}$. Then, $70 \mu \mathrm{L}$ of the supernatant in each well was transferred to a new 96 well plate, and the absorbance was recorded at $450 \mathrm{~nm}$. The protective activity was evaluated using the following equation:

$$
\begin{aligned}
\text { Protective activity }(\%)= & \left(\mathrm{A}_{\text {glutamate and sample }}-\mathrm{A}_{\text {glutamte }}\right) \\
& /\left(\mathrm{A}_{\text {no treatment }}-\mathrm{A}_{\text {glutamate }}\right) \times 100
\end{aligned}
$$

where $A_{\text {glutamate and sample }}$ is the absorbance of cells treated with both glutamate and sample at a given concentration, $A_{\text {glutamte }}$ is the absorbance for cells treated with only glutamate, $A_{\text {no treatment }}$ is the absorbance for cells with no treatment, and $A_{\text {glutamate }}$ is the absorbance for cells treated with only glutamate. $\mathrm{EC}_{50}$ is defined as the concentration of a sample that exhibited $50 \%$ cell viability compared to that of the positive control (cells with no treatment).

\section{Results and discussion Bioassay-guided fractionation}

For compound isolation, the fungus $A$. terreus was cultured in $1 \mathrm{~L}$ scale, and the culture was harvested after three days. The mycelium, separated from the broth by filtration, was extracted with $80 \%$ aqueous acetone overnight, dried in vacuo and combined with the broth again. The combined mixture of mycelium and broth was extracted stepwise with hexane, ethyl acetate (EtOAc) and buthanol $(\mathrm{BuOH})$. The EtOAc extract displayed the highest radical scavenging activity, and thus fractionated using a silica column chromatography eluting with chloroform/methanol $\left(\mathrm{CHCl}_{3} / \mathrm{MeOH}\right)$ gradient from 50:1 to $1: 1$. Active silica fractions were further separated by a Sephadex LH-20 size exclusion column chromatography eluting with $\mathrm{MeOH}$. Final purification of active fractions was achieved using reversed-phase HPLC (high performance liquid chromatography), yielding six pure compounds (compounds 1-6). In the ESIMS analysis, the molecular weights of compounds $2-\mathbf{6}$ were identical to those of previously reported butenolide derivatives. Detailed comparison of the ${ }^{1} \mathrm{H}$ and ${ }^{13} \mathrm{C}$ NMR spectra with those of known butenolide derivatives confirmed that compounds $2,3,4,5$, and $\mathbf{6}$ were butyrolactones I, II, III and VII, and aspernolide E, respectively. Although the physical property of compound $\mathbf{1}$ was nearly identical to those of compounds 2-6, the molecular weight of $\mathbf{1}$ did not match with that of any known butenolide derivative, suggesting 1 to be a potentially new butenolide derivative (Fig. 1). Thus, the structure determination of $\mathbf{1}$ was carried out using combination of spectroscopic methods including the HREIMS, and 1D and 2D NMR (Fig. 2).

\section{Structure determination of compound 1}

Butyroscavin (1) was isolated as a yellow, amorphous powder. The HREIMS spectrum of $\mathbf{1}$ exhibited a molecular ion peak at $\mathrm{m} / \mathrm{z} 370.1065$, suggesting a molecular formula as $\mathrm{C}_{20} \mathrm{H}_{18} \mathrm{O}_{7}$ (calcd. 370.1053). The ${ }^{1} \mathrm{H}$ NMR spectrum of $1\left(\mathrm{MeOH}-d_{4}\right)$ indicated the presence of four aromatic protons $\left(\delta_{\mathrm{H}} 7.60,6.87,6.64\right.$ and 6.51), two methylene protons $\left(\delta_{\mathrm{H}} 4.25\right.$ and 3.42), and one methyl protons $\left(\delta_{\mathrm{H}} 1.21\right)$. The ${ }^{13} \mathrm{C}$ NMR spectrum in combination with HMQC (Heteronuclear Multiple-Quantum Correlation) indicated the presence of two carbonyl $\left(\delta_{\mathrm{C}}\right.$ 169.8 and 169.6), ten olefinic $\left(\delta_{\mathrm{C}} 158.2,156.3,138.6\right.$, $131.3,129.2,128.0,124.1,121.9,115.4$ and 114.4), one oxygenated quaternary $\left(\delta_{\mathrm{C}} 85.7\right)$, two methylene $\left(\delta_{\mathrm{C}} 62.5\right.$, and 38.3), and one methyl $\left(\delta_{\mathrm{C}} 13.0\right)$ carbons. Four aromatic doublet proton signals that each integrate as two protons indicated the presence of two symmetric 1,4-disubstituted benzene rings. The carbon chemical shifts of C-4 $4^{\prime}\left(\delta_{\mathrm{C}} 158.2\right)$ and $\mathrm{C}-4^{\prime \prime}\left(\delta_{\mathrm{C}} 156.3\right)$ together with HMBC correlations from $\mathrm{H}-2^{\prime}\left(\delta_{\mathrm{H}} 7.60\right)$ to $\mathrm{C}-4^{\prime}\left(\delta_{\mathrm{C}} 158.2\right)$, and from $\mathrm{H}-2^{\prime \prime}\left(\delta_{\mathrm{H}} 6.64\right)$ to $\mathrm{C}-4^{\prime \prime}\left(\delta_{\mathrm{C}} 156.3\right)$ determined one of the substitutions as hydroxyl groups in both of the benzene rings. $\mathrm{HMBC}$ correlation from $\mathrm{H}-2^{\prime}\left(\delta_{\mathrm{H}} 7.60\right)$ to $\mathrm{C}-3$ $\left(\delta_{\mathrm{C}} 128.0\right)$ suggested that one of the benzene rings is connected to an olefinic carbon. A methylene substitution in another benzene ring was inferred by HMBC correlations from $\mathrm{H}-5\left(\delta_{\mathrm{H}} 3.42\right)$ to $\mathrm{C}-1^{\prime \prime}\left(\delta_{\mathrm{C}} 124.1\right)$ and $\mathrm{C}-2^{\prime \prime}\left(\delta_{\mathrm{C}}\right.$ 131.3), and an HMBC correlation from $\mathrm{H}-5\left(\delta_{\mathrm{H}} 3.42\right)$ to $\mathrm{C}-4\left(\delta_{\mathrm{C}} 85.7\right)$ connected the methylene to an oxygenated quaternary carbon. Although direct connection between the two benzene rings could not be achieved by HMBC correlations, three broad signals that account for one carbonyl, and two olefinic carbons were observed in the ${ }^{13} \mathrm{C}$ NMR spectrum, suggesting the presence of a butenolide core structure in $\mathbf{1}$. This was further supported by the fact that many butenolide derivatives have been isolated from the fungus $A$. terreus $[11,13,14]$. Detailed comparison of 
<smiles>CCOC(=O)[C@]1(Cc2ccc(O)cc2)OC(=O)C(O)=C1c1ccc(O)cc1</smiles>

1

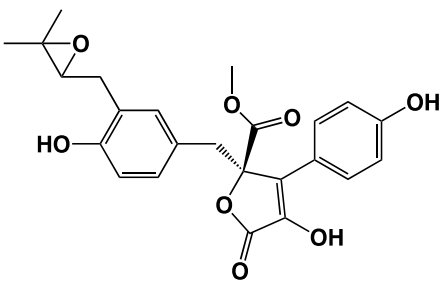

4 (Butyrolactone III)<smiles>COC(=O)[C@@]1(Cc2ccc(O)c(CC=C(C)C)c2)OC(=O)C(O)=C1c1ccc(O)cc1</smiles>

2 (Butyrolactone I)<smiles>CCOC(=O)[C@]1(Cc2ccc(O)c(CC=C(C)C)c2)OC(=O)C(O)=C1c1ccc(O)cc1</smiles>

5 (Butyrolactone VII)<smiles>COC(=O)[C@]1(Cc2ccc(O)cc2)OC(=O)C(O)=C1c1ccc(O)cc1</smiles>

3 (Butyrolactone II)<smiles>COC(=O)[C@@]1(Cc2ccc3c(c2)C=CC(C)(C)O3)OC(=O)C(O)=C1c1ccc(O)cc1</smiles>

6 (Aspernolide E)

Fig. 1 Chemical structures of isolated butenolide derivatives from the cultured A. terreus

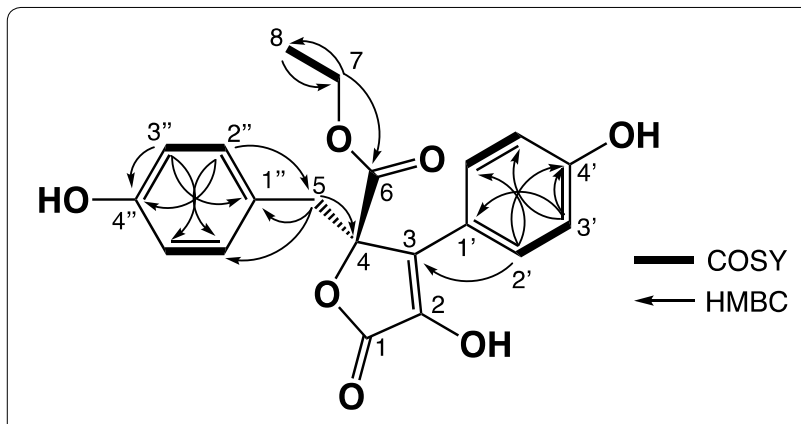

Fig. 2 2D NMR correlations used for structure determination of $\mathbf{1}$

the NMR spectra of $\mathbf{1}$ with those of previously reported butenolide derivatives from $A$. terreus suggested that the structure of $\mathbf{1}$ is similar to that of butyrolactone II [10, 14]. However, the methoxy signals were absent in the ${ }^{1} \mathrm{H}$ and ${ }^{13} \mathrm{C}$ NMR spectra of 1 . COSY correlation between oxygenated methylene $\left(\mathrm{H}_{2}-7: \delta_{\mathrm{H}} 4.25\right)$ and methyl $\left(\mathrm{H}_{3}-8\right.$ : $\left.\delta_{\mathrm{H}} 1.21\right)$ protons, and $\mathrm{HMBC}$ correlation from $\mathrm{H}_{2}-7\left(\delta_{\mathrm{H}}\right.$ $4.25)$ to $\mathrm{C}-6\left(\delta_{\mathrm{C}} 169.8\right)$ indicated that the methoxy group in butyrolactone II was replaced with an ethoxy group in $\mathbf{1}$, completing the planar structure of $\mathbf{1}$. The compound $\mathbf{1}$ possessed one chiral carbon $(\mathrm{C}-4)$, and thus the absolute configuration of $\mathrm{C}-4$ was determined by comparing the specific rotation with those of structurally related butenolide derivatives possessing the same chiral carbon. A positive specific rotation $\left(+49^{\circ}\right)$ observed for 1 indicated the absolute configuration of $\mathbf{1}$ to be the same as those of other known butenolide derivatives such as butyrolactones I $\left(+100^{\circ}\right)$, II $\left(+85^{\circ}\right)$ and III $\left(+80^{\circ}\right)[8,10]$.

\section{Biological activities of isolated compounds}

All the isolated butenolide derivatives were evaluated for their radical scavenging activities as well as protective activity against glutamate induced excitotoxicity. First, radical scavenging activity was tested using $\mathrm{DPPH}$ and $\mathrm{ABTS}^{\circ}+$ free radicals, and expressed as the amount of compound necessary to decrease the initial radical concentration by $50 \%\left(\mathrm{EC}_{50}\right.$ in $\left.\mu \mathrm{M}\right)$. All tested compounds displayed moderate scavenging activities in both assays with $\mathrm{EC}_{50}$ values of $20-70 \mu \mathrm{M}$ against the DPPH radical, and 4-25 $\mu \mathrm{M}$ against the $\mathrm{ABTS}^{\bullet+}$ radical (Table 2). It has been previously reported that

\begin{tabular}{|c|c|c|c|}
\hline & N18-RE-105 & $\mathrm{ABTS}^{++}$ & DPPH \\
\hline & \multicolumn{3}{|l|}{$\mathrm{EC}_{50}$ in $\mu \mathrm{M}$} \\
\hline 1 & NA & 9.3 & 54.3 \\
\hline 2 & 91.9 & 4.3 & 24.4 \\
\hline 3 & NA & 11.5 & 68.5 \\
\hline 4 & NA & 14.1 & 37.9 \\
\hline 5 & 130.1 & 6.7 & 37.9 \\
\hline 6 & NA & 23.4 & 58.4 \\
\hline Vitamin E & 37.2 & & \\
\hline $\mathrm{BHA}$ & & 9 & 36.5 \\
\hline Trolox & & 11.3 & 14.4 \\
\hline
\end{tabular}

NA not active 
the prenylation of flavonoids increase their antioxidant activities [3]. Therefore, higher radical scavenging activities observed for compounds 2 and 5 in both assays could be attributed to the presence of a prenyl moiety in their structures. Next, we evaluated the protective activity against glutamate induced excitotoxicity for all isolated compounds using N18-RE-105 cells. Among six compounds tested, only compounds 2 and 5 exhibited a protective activity with the $\mathrm{EC}_{50}$ values of $91.9 \mu \mathrm{M}$ and $130.1 \mu \mathrm{M}$, respectively. Although all six compounds were active in radical scavenging activity assay, only compounds $\mathbf{2}$ and $\mathbf{5}$ that contain a prenyl group on the benzene ring exhibited activity in the cell line assay. This is probably due to their higher radical scavenging activity compared to other compounds, and also an increase in lipophilicity as the attachment of a prenyl moiety would increase overall hydrophobicity of molecules.

\section{Additional file}

Additional file 1. Additional figures.

\section{Acknowledgements}

We thank the Korea Basic Science Institute (KBSI) for providing technical assistance in the NMR experiments.

\section{Authors' contributions}

HK carried out experiments. HK and JK, designed experiments, analyzed data and wrote the manuscript. JK funded experiments. Both authors read and approved the final manuscript.

\section{Funding}

This work was supported by a KRIBB Research Initiative Program (KGM5521911).

\section{Availability of data and materials}

The datasets generated or analyzed during this study are included in this published article and its Additional file 1.

\section{Competing interests}

The authors declare that they have no competing interests.

\section{Author details}

${ }^{1}$ Department of Biomedical Science and Engineering, Konkuk University, Seoul 05029, Republic of Korea. ${ }^{2}$ Korea Research Institute of Bioscience and Biotechnology (KRIBB), Cheongju, Chungbuk 28116, Republic of Korea.

Received: 13 June 2019 Accepted: 30 July 2019

Published online: 09 August 2019

\section{References}

1. Atlante A, Calissano P, Bobba A, Giannattasio S, Marra E, Passarella S (2001) Glutamate neurotoxicity, oxidative stress and mitochondria. FEBS Lett 497:1-5

2. Berry BW, Boland LM, Hoch DB, Dingledine R (1988) I-Glutamate binding site on N18-RE-105 neuroblastoma hybrid cells is not coupled to an ion channel. J Neurochem 51:1176-1183

3. Chen X, Mukwaya E, Wong MS, Zhang Y (2014) A systematic review on biological activities of prenylated flavonoids. Pharm Biol 52:655-660

4. Dessi F, Charriaut-Marlangue C, Ben-Ari Y (1994) Glutamate-induced neuronal death in cerebellar culture is mediated by two distinct components: a sodium-chloride component and a calcium component. Brain Res 650:49-55

5. Haritakun R, Rachtawee P, Chanthaket R, Boonyuen N, Isaka M (2010) Butyrolactones from the fungus Aspergillus terreus BCC 4651. Chem Pharm Bull 58:1545-1548

6. He F, Bao J, Zhang X-Y, Tu Z-C, Shi Y-M, Qi S-H (2013) Asperterrestide A, a cytotoxic cyclic tetrapeptide from the marine-derived fungus Aspergillus terreus SCSGAF0162. J Nat Prod 76:1182-1186

7. Kim JP, Kim BK, Yun BS, Ryoo IJ, Lee IK, Kim WG, Pyun YR, Yoo ID (2003) Melanocins A, B and C, new melanin synthesis inhibitors produced by Eupenicillium shearii. II. Physico-chemical properties and structure elucidation. J Antibiot (Tokyo) 56:1000-1003

8. Kiriyama N, Nitta K, Sakaguchi Y, Taguchi Y, Yamamoto Y (1977) Studies on the Metabolic Products of Aspergillus terreus. III. Metabolites of the Strain IFO 8835 (1). Chem Pharm Bull 25:2593-2601

9. Lalkovicova M, Danielisova V (2016) Neuroprotection and antioxidants. Neural Regen Res 11:865-874

10. Nitta K, Fujita N, Yoshimura T, Arai K, Yamamoto Y (1983) Metabolic products of Aspergillus terreus. IX. Biosynthesis of butyrolactone derivatives isolated from strains IFO 8835 and 4100. Chem Pharm Bull 31:1528-1533

11. Parvatkar RR, D'Souza C, Tripathi A, Naik CG (2009) Aspernolides A and B, butenolides from a marine-derived fungus Aspergillus terreus. Phytochemistry 70:128-132

12. Prentice H, Modi JP, Wu J-Y (2015) Mechanisms of neuronal protection against excitotoxicity endoplasmic reticulum stress, and mitochondrial dysfunction in stroke and neurodegenerative diseases. Oxid Med Cell Longev 2015:964518

13. Qi C, Gao W, Guan D, Wang J, Liu M, Chen C, Zhu H, Zhou Y, Lai Y, Hu Z, Zhou Q, Zhang Y (2018) Butenolides from a marine-derived fungus Aspergillus terreus with antitumor activities against pancreatic ductal adenocarcinoma cells. Bioorg Med Chem Lett 26:5903-5910

14. Rao KV, Sadhukhan AK, Veerender M, Ravikumar V, Mohan EVS, Dhanvantri SD, Sitaramkumar M, Moses Babu J, Vyas K, Om Reddy G (2000) Butyrolactones from Aspergillus terreus. Chem Pharm Bull 48:559-562

15. Re R, Pellegrini N, Proteggente A, Pannala A, Yang M, Rice-Evans C (1999) Antioxidant activity applying an improved ABTS radical cation decolorization assay. Free Radic Biol Med 26:1231-1237

\section{Publisher's Note}

Springer Nature remains neutral with regard to jurisdictional claims in published maps and institutional affiliations. 